\title{
Physiological quality of soybean seeds of cultivars submitted to harvesting delay and its association with seedling emergence in the field ${ }^{1}$
}

\author{
Fábio Oliveira Diniz*, Múcio Silva Reis ${ }^{3}$, Luiz Antônio dos Santos Dias', \\ Eduardo Fontes Araújo ${ }^{3}$, Tuneo Sediyama ${ }^{3}$, Camilla Atsumi Sediyama ${ }^{3}$
}

\begin{abstract}
With the aim of studying the relationship between the physiological quality of soybean seeds submitted to three harvest times and seedling emergence in the field, seeds of cultivars UFV-16, Splendor, Vencedora, Confiança, UFV-18, UFV-TN 105, Garantia and Celeste were harvested at stages R8, R8+15 and R8+30 days. The following tests were performed: accelerated aging, electrical conductivity, emergence in sand, emergence speed index and seedling emergence in the field. Germination and vigor were reduced in seeds harvested at 30 days after stage R8 in all the tests, except for the accelerated aging test, which showed a decline in vigor seeds harvested with a delay of 15 days. Seeds of cultivars UFV-16, Confiança and Garantia showed lower physiological quality in most tests, while the seeds of cultivar Celeste had higher physiological quality than the others. There was similarity between the test results of seed quality and seedling emergence in the field.
\end{abstract}

Index terms: Glycine max, seed vigor, harvest time.

\section{Qualidade fisiológica de sementes de cultivares de soja submetidas ao retardamento de colheita e sua relação com a emergência das plântulas em campo}

\begin{abstract}
RESUMO - Com o objetivo de estudar as relações entre a qualidade fisiológica de sementes de soja submetidas a três épocas de colheita e a emergência das plântulas em campo, sementes das cultivares UFV-16, Splendor, Vencedora, Confiança, UFV-18, UFV-TN 105, Garantia e Celeste foram colhidas nos estádios R8, R8+15 e R8+30 dias. Realizaram-se os testes de germinação, envelhecimento acelerado, condutividade elétrica, emergência em areia, índice de velocidade e emergência de plântulas em campo. A germinação e o vigor foram reduzidos nas sementes colhidas aos 30 dias após o estádio R8, em todas as avaliações, à exceção do teste de envelhecimento acelerado, que revelou queda do vigor nas sementes colhidas com 15 dias de retardamento. Sementes das cultivares UFV-16, Confiança e Garantia foram as que apresentaram, na maioria dos testes, qualidade fisiológica inferior e as da cultivar Celeste, qualidade fisiológica superior às demais. Houve similaridade entre os resultados dos testes de avaliação da qualidade fisiológica de sementes com a emergência das plântulas em campo.
\end{abstract}

Termos para indexação: Glycine max, vigor de semente, época de colheita.

\section{Introduction}

Maximum potential for germination and seed vigor occurs during physiological maturity. However, seeds have high water content at this stage, which hinders mechanized harvesting (Marcos-Filho, 2005). After physiological maturity, seed quality begins to decrease through the natural process of deterioration (Krzyzanowski et al, 2008), especially when harvesting is delayed, and also under unfavorable weather conditions.

Several studies show that delaying the harvest from stage R8 can impair germination and vigor of soybean seeds. The intensity of this effect depends on the residence time

${ }^{1}$ Submitted on $02 / 19 / 2012$. Accepted for publication on 12/10/2012. ${ }^{2}$ Instituto Federal de Educação, Ciência e Tecnologia do Piauí - IFPI, 64860-000 - Uruçuí, PI, Brasil. of seeds in the field, their genotype and climatic conditions such as temperature and precipitation. (Vieira et al., 1982; Miranda et al., 1996). Harvesting delay can also be stressful to seeds, which may have different responses depending on their genotype. However, this procedure can be used with the objective of selecting soybean genotypes for high quality seeds (França-Neto et al., 1994; Lima et al., 2007).

Vigor tests have been widely used to identify possible differences in physiological quality of seed lots. However, the effect cannot always be fully evaluated by only one test, which is why the use of many other tests is advisable (Marcos-Filho et al., 1987). For the tests to be effective, good correlation is

${ }^{3}$ Departamento de Fitotecnia, Universidade Federal de Viçosa - UFV, 36570-000 - Viçosa, MG, Brasil.

*Corresponding author < dinizagro@gmail.com> 
required with seedling emergence in the field, where climatic conditions are quite varied.

Methodologies have been proposed, tested and compared, in order to correlate laboratory tests with seedling emergence in the field, to differentiate seed vigor across genotypes. One of them is the use of harvesting delay (Santos et al., 2005). However, as shown by Schuab et al. (2006), considering only the correlation analysis is not enough to interpret the results of laboratory tests and seedling emergence in the field. There are still few studies comparing results obtained in different tests that assess the physiological quality of seeds and seedling emergence in the field.

Thus, the aim of this study was to evaluate and compare the relationship between seed quality of soybean cultivars submitted to three harvest times and seedling emergence in the field.

\section{Material and Methods}

The analyses were made at the Laboratory of Soybean Improvement and Seed Research from the Department of Plant Science at UFV, and the cultivars were produced in the Experimental Field Prof. Diogo Alves de Mello, in the agricultural year 2007/08 in Viçosa, Minas Gerais. Seeds were produced from eight soybean cultivars: UFV-16, Splendor, Vencedora, Confiança, UFV-18, UFV-TN 150, Garantia and Celeste. Plants were harvested at three times: stage R8 (when $95 \%$ of pods have typical coloration of mature pods), 15 and 30 days after this stage.

The experiment had a randomized block, split-plot design with four replications. The plots were represented by the eight cultivars and the subplots, by the three harvest times. Each plot consisted of eight $5 \mathrm{~m}$ long rows, inter-spaced at $0.5 \mathrm{~m}$. The subplots were formed by two of these rows, with two remaining sides as the plot borders.

The weather conditions were monitored at harvest time (March 31 to May 28, 2008), and the climatic data were provided by the Department of Meteorology, Department of Agricultural Engineering/UFV.

After harvest, plants were taken to shade and when the water content of the seeds ranged between $12 \%$ and $13 \%$, they were threshed in a stationary thresher. After being cleaned, the seeds were sieved through round hole sieves with diameters of $4.76 \mathrm{~mm}$ and $5.16 \mathrm{~mm}$. Then, they were packed in bags made of cotton cloth and kept in ambient conditions in the laboratory, where they were submitted to the following tests:

Germination: for each treatment, and field replicate, four replications of 50 seeds were placed between three sheets of paper towel moistened with three times as much distilled water as the weight of the dry paper towel. After the towels were rolled up, they were taken to a germinator set to a constant temperature of $25{ }^{\circ} \mathrm{C} \pm 2{ }^{\circ} \mathrm{C}$. Evaluations were performed at five (first count) and eight (final count) days after the test was performed (Brasil, 2009).

Accelerated aging: approximately 250 seeds were sowed on a screen of aluminum fixed inside plastic germination boxes $(11.0 \times 11.0 \times 3.0 \mathrm{~cm})$ containing $40 \mathrm{~mL}$ of distilled water. The germination boxes were kept in a BOD incubator at $41^{\circ} \mathrm{C}$ for 48 hours. After this period, 200 seeds/treatment were divided into four replications of 50 seeds, and germinated as described previously (germination test). An evaluation was made on the fifth day after sowing, and the percentage of normal seedlings was calculated (AOSA, 1983).

Electrical conductivity: two replications of 50 seeds of each treatment and field replicate were placed in $300 \mathrm{~mL}$ plastic cups and weighed on an analytical balance $(0.001 \mathrm{~g}$ readability); then, $75 \mathrm{~mL}$ of distilled water was added in each container. The containers were placed in a BOD incubator at a constant temperature of $25^{\circ} \mathrm{C}$. After 24 hours of incubation, the seeds were agitated gently for homogenization of the solution, and electrical conductivity was measured with a conductivity meter (DIGIMED CD-31). The results were expressed as $\mu \mathrm{S} . \mathrm{cm}^{-1} \cdot \mathrm{g}^{-1}$ (Vieira and Krzyzanowski, 1999).

Emergence in sand: this test was conducted in a greenhouse using two replications of 50 seeds of each treatment and field replicate, sown in plastic trays containing washed and sterilized sand. The minimum and maximum temperatures recorded during the test were $20^{\circ} \mathrm{C}$ and $28^{\circ} \mathrm{C}$, respectively. Substrate moisture was kept on a daily basis through moderate irrigation. Counts were performed daily, and the emergence speed index was calculated according to the formula proposed by Maguire (1962) and at the end of the 11th day, when the number of seedlings was stabilized, and the first pair of unifoliolate leaves was completely open, the final count was performed and the result was expressed as a percentage of seedlings.

Field emergence: two replications of 50 seeds of each treatment and field replicate were sown at a depth of approximately $3.0 \mathrm{~cm}$, arranged in $1 \mathrm{~m}$ rows inter-spaced at $0.5 \mathrm{~m}$. Observations were made daily, and seedling count started as soon as stability was observed of the number of seedlings with the first pair of completely open unifoliolate leaves, i.e. on the 13th day after sowing. The percentage of emergence was calculated.

The data were tested for normality (Lillifors' Test) and homogeneity of residual variances across treatments (Cochran's test) before the analyses of variance and correlation were made. Comparisons across means were made by Tukey's test at $5 \%$ probability. To perform the analysis of variance, the 
percentage data of the accelerated aging test were previously transformed to arcsine $\sqrt{x / 100}$. The software SAS was used (Delwiche and Slaughter, 2003).

\section{Results and Discussion}

During the harvest period, relative humidity remained between $70 \%$ and $92 \%$, with average temperatures ranging from $15.5{ }^{\circ} \mathrm{C}$ to $23.1{ }^{\circ} \mathrm{C}$. There was little and sparse rainfall, occurring only in the last twenty-five days of harvest. The highest rainfall recorded was $11.6 \mathrm{~mm}$. The environmental conditions at the time of harvest directly influence the quality of seeds, mainly soybeans.

The average percentage of seed germination in the second count was virtually the same observed at the first count. This behavior can be explained by the high incidence of fungi on seeds, favoring the reduction of germination at the second count. This is a common occurrence of fungi on seeds resulting from harvesting delay, and the fungi Fusarium spp. and Phomopsis spp. are those that most affect the results of the germination test (Henning, 2005).

There was no difference in the germination of seeds harvested at stages $\mathrm{R} 8$ and $\mathrm{R} 8+15$ days, except for those harvested 30 days after stage $\mathrm{R} 8$ (Table 1). The results show that the harvesting delay of 30 days after stage $\mathrm{R} 8$ significantly reduced seed germination, confirming the results found by Braccini et al. (2000). There is significant difference in the behavior of cultivars, especially cultivar Celeste, whose performance was better than that of cultivar Garantia.

Table 1. Germination (\%) of seeds of eight soybean cultivars harvested at three times ( $\mathrm{R} 8, \mathrm{R} 8+15$ and $\mathrm{R} 8+30$ days).

\begin{tabular}{lcccc}
\hline \multirow{2}{*}{ Cultivar } & \multicolumn{3}{c}{ Harvest time } & \multirow{2}{*}{ Mean } \\
\cline { 2 - 4 } & R8 & R8+15 & R8+30 & \\
\hline UFV-16 & 74 & 73 & 48 & $65 \mathrm{bc}$ \\
Splendor & 84 & 77 & 67 & $76 \mathrm{abc}$ \\
Vencedora & 86 & 83 & 68 & $79 \mathrm{ab}$ \\
Confiança & 82 & 76 & 60 & $73 \mathrm{abc}$ \\
UFV-18 & 84 & 78 & 71 & $78 \mathrm{abc}$ \\
UFV-TN 105 & 86 & 84 & 75 & $82 \mathrm{ab}$ \\
Garantia & 68 & 60 & 53 & $60 \mathrm{c}$ \\
Celeste & 92 & 91 & 88 & $90 \mathrm{a}$ \\
\hline \multicolumn{1}{c}{ Mean } & $82 \mathrm{~A}$ & $78 \mathrm{~A}$ & $66 \mathrm{~B}$ & 75 \\
\hline
\end{tabular}

Means followed by the same letter do not differ by Tukey's test $(\mathrm{p}<0.05)$.

The different behavior among cultivars was also reported by some researchers (Santos et al., 1996; Giurizatto et al., 2003; Lima et al., 2007), which makes harvesting delay an effective method to differentiate genotypes as regards the physiological quality of soybean seeds.

Table 2 shows that, after accelerated aging, a harvesting delay of 15 days after stage R8 was sufficient to reduce seed germination, as opposed to the germination test, where reduction occurred only in the seeds harvested 30 days after stage R8. As for the cultivars, it can be seen that the cultivar Celeste differed statistically from cultivars Garantia, Confiança and UFV-16. The latter two also differed from cultivars Vencedora and UFV-TN 105. These results are similar to those obtained in the germination test, where cultivar Celeste had the best germination results, while cultivars Garantia and UFV-16 had the worst.

Table 2. Germination (\%) after accelerated aging of seeds of eight soybean cultivars harvested at three times ( R8, $\mathrm{R} 8+15$ and $\mathrm{R} 8+30$ days).

\begin{tabular}{lcccc}
\hline \multirow{2}{*}{ Cultivar } & \multicolumn{3}{c}{ Harvest time } & \multirow{2}{*}{ Mean } \\
\cline { 2 - 4 } & $\mathrm{R} 8$ & $\mathrm{R} 8+15$ & $\mathrm{R} 8+30$ & \\
\hline UFV-16 & 92 & 84 & 61 & $79 \mathrm{c}$ \\
Splendor & 95 & 89 & 79 & $88 \mathrm{abc}$ \\
Vencedora & 96 & 96 & 84 & $92 \mathrm{ab}$ \\
Confiança & 90 & 88 & 74 & $84 \mathrm{c}$ \\
UFV-18 & 96 & 93 & 75 & $88 \mathrm{abc}$ \\
UFV-TN 105 & 96 & 96 & 86 & $93 \mathrm{ab}$ \\
Garantia & 90 & 89 & 79 & $86 \mathrm{bc}$ \\
Celeste & 97 & 96 & 88 & $94 \mathrm{a}$ \\
\hline \multicolumn{1}{c}{ Mean } & $94 \mathrm{~A}$ & $92 \mathrm{~B}$ & $78 \mathrm{C}$ & 88 \\
\hline
\end{tabular}

Means followed by the same letter do not differ by Tukey's test $(\mathrm{p}<0.05)$ Values transformed into arccosine $\sqrt{x / 100}$ for analysis of variance and subsequently, the means were untransformed.

Braccini et al. (2003), working with soybean seeds harvested at stages $\mathrm{R} 8$ and $\mathrm{R} 8+30$ days, observed in the results of the accelerated aging test that soybean seeds had reduced vigor with a late harvest. They also found different behavior among cultivars, i.e., cultivars with the best levels of vigor at harvest at stage $\mathrm{R} 8$ did not kept physiological quality when the harvest was delayed.

Seeds harvested at stages R8 and R8+15 showed lower electrolyte leakage than seeds harvested 30 days after stage R8. These results show a trend in all tests, whereby a further delay of the harvest caused the greatest losses of physiological seed quality. Thus, it can be seen that delaying the harvest for 30 days subjected the seeds to conditions such as high temperatures and inadequate oscillation of relative humidity, which are deleterious to the maintenance of seed quality. Under such conditions, the cell membranes of the seeds are damaged and lose their selectivity, triggering the leakage of solutes to the external environment. The results for the cultivars were somewhat different from those obtained 
in the germination and accelerated aging tests, in which a significant difference was observed only between cultivar Garantia compared to Splendor and Vencedora (Table 3). It should be noted that the results highlight the fact that the lot of cultivar Garantia has lower quality, confirming the results obtained for germination and accelerated aging. However, the results for cultivar UFV-16 confirm those obtained in previous tests, because in the electrical conductivity test, this cultivar ranks among the cultivars of intermediate to higher quality, something which did not occur in the other tests.

Table 3. Means of the electrical conductivity of leachates $\left(\mu \mathrm{S} . \mathrm{cm}^{-1} \cdot \mathrm{g}^{-1}\right)$ of the seeds of eight soybean cultivars harvested at three times $(\mathrm{R} 8, \mathrm{R} 8+15$ and $\mathrm{R} 8+30$ days).

\begin{tabular}{lcccl}
\hline \multirow{2}{*}{ Cultivar } & \multicolumn{3}{c}{ Harvest time } & \multirow{2}{*}{ Mean } \\
\cline { 2 - 4 } & $\mathrm{R} 8$ & $\mathrm{R} 8+15$ & $\mathrm{R} 8+30$ & \\
\hline UFV-16 & 56 & 60 & 74 & $63 \mathrm{ab}$ \\
Splendor & 45 & 51 & 60 & $52 \mathrm{a}$ \\
Vencedora & 48 & 46 & 63 & $52 \mathrm{a}$ \\
Confiança & 54 & 56 & 70 & $60 \mathrm{ab}$ \\
UFV-18 & 58 & 68 & 73 & $66 \mathrm{ab}$ \\
UFV-TN 105 & 55 & 55 & 63 & $58 \mathrm{ab}$ \\
Garantia & 62 & 67 & 78 & $69 \mathrm{~b}$ \\
Celeste & 49 & 52 & 63 & $55 \mathrm{ab}$ \\
\hline \multicolumn{1}{c}{ Mean } & $53 \mathrm{~A}$ & $57 \mathrm{~A}$ & $68 \mathrm{~B}$ & 59 \\
\hline
\end{tabular}

Means followed by the same letter do not differ by Tukey's test $(\mathrm{p}<0.05)$.

Santos et al. (2005) found no differences among genetic materials in the results of the electrical conductivity test of seeds harvested at stage R8, an effect not observed with seeds harvested at 15 and 30 days after this stage, where they observed an increase in the electrical conductivity of seed exudates, differently for each cultivar.

As in the other tests, there was a significant difference in seedling emergence in sand across harvest times only when the seeds were harvested 30 days after stage R8 (Table 4). The behavior of the cultivars was similar; cultivar UFV-16 had lower quality, followed by cultivar Confiança. The observed values were much higher than those of the germination test. According to França-Neto and Henning (1992), seed germination in sand or soil is less affected by fungi, especially those present in the integument.

Unlike other tests to determine physiological quality, the emergence speed index in sand was the only test that showed a significant interaction cultivar $\mathrm{x}$ harvest time (Table 5). In the first two harvest times, the cultivars showed similar emergence speed indexes. However, in the third harvest time, the cultivars behaved differently.
Table 4. Means of the percentage of seedling emergence in sand of the eight soybean cultivars harvested at three times ( $R 8, \mathrm{R} 8+15$ and $\mathrm{R} 8+30$ days).

\begin{tabular}{lcccc}
\hline \multirow{2}{*}{ Cultivar } & \multicolumn{3}{c}{ Harvest time } & \multirow{2}{*}{ Mean } \\
\cline { 2 - 4 } & R8 & R8+15 & R8+30 & \\
\hline UFV-16 & 88 & 79 & 55 & $74 \mathrm{c}$ \\
Splendor & 96 & 86 & 82 & $88 \mathrm{ab}$ \\
Vencedora & 96 & 92 & 80 & $89 \mathrm{ab}$ \\
Confiança & 87 & 85 & 61 & $78 \mathrm{bc}$ \\
UFV-18 & 96 & 89 & 79 & $88 \mathrm{ab}$ \\
UFV-TN 105 & 94 & 94 & 81 & $89 \mathrm{ab}$ \\
Garantia & 94 & 91 & 73 & $86 \mathrm{abc}$ \\
Celeste & 96 & 96 & 85 & $92 \mathrm{a}$ \\
\hline Mean & $93 \mathrm{~A}$ & $89 \mathrm{~A}$ & $74 \mathrm{~B}$ & 85 \\
\hline
\end{tabular}

Means followed by the same letter do not differ by Tukey's test $(\mathrm{p}<0.05)$.

Table 5. Mean speed rate of seedling emergence in sand of the eight soybean cultivars harvested at three times $(\mathrm{R} 8$, $\mathrm{R} 8+15$ and $\mathrm{R} 8+30$ days).

\begin{tabular}{lclll}
\hline \multirow{2}{*}{ Cultivar } & \multicolumn{3}{c}{ Harvest time } & \multirow{2}{*}{ Mean } \\
\cline { 2 - 4 } & $\mathrm{R} 8$ & $\mathrm{R} 8+15$ & $\mathrm{R} 8+30$ & \\
\hline UFV-16 & $7.6 \mathrm{Aa}$ & $6.8 \mathrm{Aa}$ & $4.9 \mathrm{Bb}$ & 6.4 \\
Splendor & $8.3 \mathrm{Aa}$ & $7.3 \mathrm{ABa}$ & $6.8 \mathrm{Bab}$ & 7.4 \\
Vencedora & $8.1 \mathrm{Aa}$ & $8.0 \mathrm{Aa}$ & $7.1 \mathrm{Aab}$ & 7.8 \\
Confiança & $8.0 \mathrm{Aa}$ & $7.1 \mathrm{Aa}$ & $5.3 \mathrm{Bb}$ & 6.8 \\
UFV-18 & $8.0 \mathrm{Aa}$ & $7.3 \mathrm{Aa}$ & $7.1 \mathrm{Aab}$ & 7.5 \\
UFV-TN 105 & $8.3 \mathrm{Aa}$ & $8.3 \mathrm{Aa}$ & $7.4 \mathrm{Aab}$ & 8.0 \\
Garantia & $8.3 \mathrm{Aa}$ & $7.9 \mathrm{ABa}$ & $6.8 \mathrm{Bab}$ & 7.6 \\
Celeste & $9.1 \mathrm{Aa}$ & $9.0 \mathrm{Aa}$ & $8.8 \mathrm{Aa}$ & 9.0 \\
\hline \multicolumn{1}{c}{ Mean } & 8.2 & 7.7 & 6.8 & 7.5 \\
\hline
\end{tabular}

Means followed by the same lowercase in the column and uppercase on the line, do not differ by Tukey's test $(\mathrm{p}<0.05)$.

An analysis of the third harvest time showed that cultivars UFV-16 and Confiança were different from Celeste because they had the lowest emergence speed indexes. However, they did not differ from the other cultivars. Moreover, these two cultivars, along Splendor and Garantia, when harvested 30 days after stage $\mathrm{R} 8$, had poorer results than those in the first two harvest times. They were shown to be less tolerant to the factors that cause deterioration when kept in the field until 30 days after stage R8. These results for emergence speed index corroborate those obtained by Dias et al. (2005), as a reduction was observed in the speed of seedling emergence with a harvest delay of 30 days after stage $\mathrm{R} 8$.

Table 6 shows that the seeds harvested in the third time (30 days after stage $\mathrm{R} 8$ ) showed lower seedling emergence than those harvested at stages $\mathrm{R} 8$ and $\mathrm{R} 8+15$ days. This negative effect of harvest on seed physiological quality, just 
30 days after stage R8, was also observed in the other tests, except for the accelerated aging test. There was no difference among most cultivars, except for UFV-16, which showed lower quality compared to the others. Although no statistical differences were observed among most cultivars, they can be grouped into three categories according to the emergence percentage values shown: the lower quality group, as already mentioned, includes UFV-16 with $65 \%$ of emergence; the intermediate quality group has cultivars Confiança, Garantia and Splendor, with $76 \%, 77 \%$ and $79 \%$ of emergence, respectively; and the group with emergence above $80 \%$, with cultivars Vencedora, UFV-18, UFV-TN 105 and Celeste, which represent the seeds with the highest vigor.

Although the results for emergence in sand and in the field were superior to those for seed germination in paper towel, the results of the three tests were similar, i.e., a harvest delay of 30 days alone after stage R8 was enough to reduce germination and seedling emergence; likewise, the behavior of the cultivars was different; the seeds of UFV-16, Confiança and Garantia showed lower physiological quality than the other cultivars.

The linear or Pearson's correlations were significant ( $p>0.01$ ) for all pairs of tests performed to evaluate the physiological quality of seeds of eight soybean cultivars submitted to three harvest times (Table 7). All correlations were positive, except for the correlation with the data of the electrical conductivity test. This is explained by the principle of the test itself. The results of tests for seed quality and seedling emergence in the field were similar.
Schuab et al. (2006) obtained similar results when they compared different tests that evaluate the vigor of soybean seeds, and they observed that most of the tests used were correlated with seedling emergence in the field.

According to Schuab et al. (2002), the relationship between the results of tests to assess seed quality and field performance is directly associated with environmental conditions, because according to Marcos-Filho (1999), the ability of laboratory tests to estimate the potential seedling emergence in the field is reduced as environmental conditions become less appropriate, and thus, virtually inexistent under extremely unfavorable conditions.

Table 6. Means of the percentage of seedling emergence in the field of eight soybean cultivars harvested at three times (R8, R8+15 and $\mathrm{R} 8+30$ days).

\begin{tabular}{lcccc}
\hline \multirow{2}{*}{ Cultivar } & \multicolumn{3}{c}{ Harvest time } & \multirow{2}{*}{ Mean } \\
\cline { 2 - 4 } & $\mathrm{R} 8$ & $\mathrm{R} 8+15$ & $\mathrm{R} 8+30$ & \\
\hline UFV-16 & 75 & 72 & 49 & $65 \mathrm{~b}$ \\
Splendor & 83 & 79 & 69 & $77 \mathrm{ab}$ \\
Vencedora & 88 & 88 & 76 & $84 \mathrm{a}$ \\
Confiança & 82 & 78 & 67 & $76 \mathrm{ab}$ \\
UFV-18 & 89 & 89 & 71 & $83 \mathrm{a}$ \\
UFV-TN 105 & 90 & 88 & 75 & $84 \mathrm{a}$ \\
Garantia & 86 & 80 & 71 & $79 \mathrm{ab}$ \\
Celeste & 87 & 87 & 79 & $84 \mathrm{a}$ \\
\hline \multicolumn{1}{c}{ Mean } & $85 \mathrm{~A}$ & $82 \mathrm{~A}$ & $70 \mathrm{~B}$ & 79 \\
\hline
\end{tabular}

Means followed by the same letter do not differ by Tukey's test $(\mathrm{p}<0.05)$.

Table 7. Simple correlation between the first germination count (FGC), germination (GER), accelerated aging (AA), seedling emergence (EMEGa) and the emergence speed in sand (ESI), seedling emergence in the field (EMERGc) and electrical conductivity (EC) of seeds of eight soybean cultivars harvested at three times (R8, R8+15 and R8+30 days).

\begin{tabular}{ccccccc}
\hline Variable & GER (\%) & AA $(\%)$ & EMERGa $(\%)$ & ESI & EMERGc $(\%)$ & EC $\left(\mu\right.$ S.cm $\left.{ }^{-1} \cdot \mathrm{g}^{-1}\right)$ \\
\hline FGC (\%) & $0.999^{* *}$ & $0.748^{* *}$ & $0.721^{* *}$ & $0.664^{* *}$ & $0.697^{* *}$ & $-0.687^{* *}$ \\
GER (\%) & & $0.749^{* *}$ & $0.721^{* *}$ & $0.664^{* *}$ & $0.696^{* *}$ & $-0.687^{* *}$ \\
AA (\%) & & & $0.834^{* *}$ & $0.726^{* *}$ & $0.827^{* *}$ & $-0.690^{* *}$ \\
EMERGa (\%) & & & $0.854^{* *}$ & $0.797^{* *}$ & $-0.641^{* *}$ \\
ESI & & & & $0.705^{* *}$ & $-0.483^{* *}$ \\
EMERGc (\%) & & & & & $-0.587^{* *}$ \\
\hline
\end{tabular}

** significant at $1 \%$ probability by the t-test.

\section{Conclusions}

Germination and vigor are reduced in seeds harvested at 30 days after stage $\mathrm{R} 8$.

Seeds of cultivars UFV-16, Confiança and Garantia showed lower physiological quality than the other cultivars in most tests.

The results obtained by different tests to evaluate the physiological quality of seeds are confirmed by the test results for seedling emergence in the field.

\section{References}

ASSOCIATION OF OFFICIAL SEED ANALYSTS. Seed vigor testing handbook. East Lansing: AOSA, 1983. 93p. (Contribution 32). 
BRACCINI, A.L.; ALBRECHT, L.P.; ÁVILA, M.R.; SCAPIM, C.A.; BIO, F.E.I.; SCHUAB, S.R.P. Qualidade fisiológica e sanitária das sementes de quinze cultivares de soja (Glycine $\max (\mathrm{L}$.) Merrill) colhidas na época normal e após o retardamento da colheita. Acta Scientiarum Agronomy, v.25, n.2, p.449-457, 2003. http://periodicos.uem.br/ojs/index.php/actasciagron/article/ view/2153/1611

BRACCINI, A.L.; REIS, M.S.; BRACCINI, M.C.L.; SCAPIM, C.A.; MOTTA, I.S. Germinação e sanidade de sementes de soja (Glycine max (L.) Merrill) colhidas em diferentes épocas. Acta Scientiarum Agronomy, v.22, n.4, p.1017-1022, 2000. http://periodicos.uem.br/ojs/index.php/actasciagron/ article/view/2868/2047

BRASIL. Ministério da Agricultura, Pecuária e Abastecimento. Regras para análise de sementes. Ministério da Agricultura, Pecuária e Abastecimento. Secretaria de Defesa Agropecuária, Brasília, DF: MAPA/ACS, 2009. 395p http://www.bs.cca.ufsc.br/publicacoes/regras\%20analise\%20sementes.pdf

DELWICHE, L.D.; SLAUGHTER, S.J. The littler SAS book: a primer. Cary: SAS Institute, 2003. 268p.

DIAS, A.C.P.; REIS, M.S.; SEDIYAMA, C.S.; MOREIRA, M.A.; ROCHA, V.S. Qualidade fisiológica de sementes de soja (Glycine $\max ($ L.) Merrill) sem lipoxigenases. Revista Ceres, v.52, n.301, p.453-466, 2005. http://www. scielo.br/pdf/rbs/v24n1/v24n1a20.pdf

FRANÇA-NETO, J.B.; HENNING, A.A.; KRZYZANOWSKI, F.C. Seed production and technology for the tropics. In: EMBRAPA-CNPSo. (Ed.). Tropical soybean: improvement and production. Rome: FAO, 1994. p.217-240.

FRANÇA-NETO, J.B.; HENNING, A.A. DIACOM: diagnóstico completo da qualidade da semente de soja. Londrina: EMBRAPA/CNPSo, 1992. 22p. (EMBRAPA/CNPSo. Circular Técnica, 10).

GIURIZATTO, M.I.K.; SOUZA, L.C.F.; ROBAINA, A.D.; GONÇALVES, M.C. Efeito da época de colheita e da espessura do tegumento sobre a viabilidade e o vigor de sementes de soja. Ciência e Agrotecnologia, v.27, n.4, p.771-779, 2003. http://www.scielo.br/scielo.php?script=sci pdf\&pid=s1413-70542003000400005\&lng=en\&nrm=iso\&tlng=pt_

HENNING, A.A. Patologia e tratamento de sementes: noções gerais. 2.ed. Londrina: Embrapa Soja, 2005. 52p. (Embrapa Soja. Documentos, 264).

KRZYZANOWSKI, F.C.; FRANÇA-NETO, J.B.; HENNING, A.A.; COSTA, N.P. O controle de qualidade agregando valor à semente de soja - Série Sementes. Londrina: Embrapa Soja, 2008. 12p. (Embrapa Soja. Circular Técnica, 54)

LIMA, W.A.A.; BORÉM, A.; DIAS, D.C.F.S.; MOREIRA, M.A.; DIAS, L.A.S.; PIOVESAN, N.D. Retardamento de colheita como método de diferenciação de genótipos de soja para qualidade de sementes. Revista Brasileira de Sementes, v.29, n.1, p.186-192, 2007. http://www.scielo.br/scielo.php?script=sci pdf\&pid=s0101-31222007000100026\&lng=pt\&nrm=iso\&tlng=pt_
MAGUIRE, J.D. Speed of germination-aid in selection and evaluation for seedling emergence and vigor. Crop Science, v.2, n.2, p.176-177, 1962.

MARCOS-FILHO, J. Fisiologia de sementes de plantas cultivadas. Piracicaba: FEALQ, 2005. 495p

MARCOS-FILHO, J. Teste de vigor: importância e utilização. In KRZYZNOWSKI, F.C.; VIEIRA, R.D.; FRANÇA-NETO, J.B. (Eds.) Vigor de sementes: conceito e testes. Londrina: ABRATES, 1999. Cap.1, p.1-21.

MARCOS-FILHO, J.; CÍCERO, S.M.; SILVA, W.R. Avaliação da qualidade fisiológica das sementes. Piracicaba, FEALQ, 1987. 230p.

MIRANDA, G.V.; SOUZA, P.I.M.; MOREIRA, C.T.; SPEHAR, C.R. Efeito de épocas de colheita e debulha sobre a qualidade física e fisiológica de sementes da soja. Revista Ceres, v.43, n.249, p.663-673, 1996. http://www. ceres.ufv.br/CERES/revistas/V43N249P05496.pdf

SANTOS, M.R.; REIS, M.S.; SEDIYAMA, T.; SEDIYAMA, C.S.; DIAS, L.A.S.; ARAÚJO, E.F. Qualidade fisiológica e sanitária de sementes de soja submetidas a diferentes épocas de colheita e correlações com a emergência de plântulas no campo. Revista Ceres, v.52, n.302, p.535-554, 2005. http://www. ceres.ufv.br/ceres/revistas/v52n302p04705.pdf

SANTOS, V.L.M.; SILVA, R.F.; CARDOSO, A.A.; SEDIYAMA, T. Avaliação da produtividade e da qualidade das sementes de genótipos de soja (Glycine $\max (\mathrm{L}$.) Merrill), colhidas na maturação fisiológica e trinta dias após o ponto de colheita. Revista Brasileira de Sementes, v.18, n.1, p.50-56, 1996. http://www.abrates.org.br/revista/artigos/1996/v18n1/artigo09.pdf

SCHUAB, S.R.P.; BRACCINI, A.L.; SCAPIM, C.A.; FRANÇA-NETO, J.B.; MESCHEDE, D.K. Potencial fisiológico de sementes de soja e sua relação com a emergência das plântulas em campo. Acta Scientiarum Agronomy, v.28, n.4, p.553-561, 2006. http://periodicos.uem.br/ojs/index. php/actasciagron/article/view/928/928

SCHUAB, S.R.P.; BRACCINI, A.L.; FRANÇA-NETO, J.B.; SCAPIM, A.L.; MESCHEDE, D.K. Utilização da taxa de crescimento das plântulas na avaliação do vigor de sementes de soja. Revista Brasileira de Sementes, v.24, n.2, p.90-95, 2002. http://www.scielo.br/pdf/rbs/v24n2/v24n2a15.pdf

VIEIRA, R.D.; KRZYZANOWSKI, F.C. Teste de condutividade elétrica. In KRZYZANOWSKI, F.C.; VIEIRA, R.D.; FRANÇA-NETO, J.B. (Ed.) Vigor de sementes: conceitos e testes. Londrina: ABRATES, 1999. cap.4, p.1-26.

VIEIRA， R.D.; SEDIYAMA， T.; SILVA， R.F.; SEDIYAMA, C.S ; THIÉBAUT, J.T. Efeito do retardamento da colheita, sobre a qualidade de sementes de soja cv "UFV-2". Revista Brasileira de Sementes, v.4, n.2, p.922, 1982. http://www.abrates.org.br/revista/artigospublicados/login.php 